"1 Thomas DC. General relative-risk models for survival time and matched casecontrol analysis. Biometrics 1981;37:673-86.

Kolterman OG, Gray RS, Griffin J, et al. Receptor and post-receptor defects contribute to the insulin resistance in noninsulin-dependent diabetes mellitus. Clin Invest $1981 ; 68: 957-69$

${ }^{3}$ Olefsky $\mathrm{JM}$, Kolterman OG. In vivo studies of insulin resistance in human obesity. In: Bjorntop P, Cairella M, Howard AN, eds. Recent advances in obesity research Ponz de Leon $M$, Ferenderes $R$, Carulli

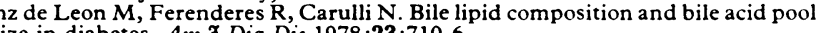
size in diabetes. Am $\mathcal{F}$ Dig Dis 1978;23:710-6.

Kajiyama G, Oyamada K, Nakao S, Miyoshi A. The effect of diabetes mellitus and $221-7$

"Bennion LJ, Grundy SM. Effects of diabetes mellitus on cholesterol metabolism in man. $N$ Engl 7 Med 1977;296:1365-71.

7 Haber GB, Heaton KW. Lipid composition of bile in diabetes and obesity-matched

controls. Gut 1979;20:518-22.
"Szanto S, Yudkin J. The effect of dietary sucrose on blood lipids, serum insulin, platelet adhesiveness and body weight in human volunteers. Postgrad Med $\mathfrak{f}$ $1969 ; 45: 602-7$.

" Reiser S, Handler HB, Gardner LB, Hallfrisch JG, Michaelis OE, Prather ES. Isocaloric exchange of dietary starch and sucrose in humans. II. Effect on fasting blood insulin, glucose and glucagon and on insulin and glucose response to

作

${ }^{31}$ Boston Collaborative Drug Surveillance Programme. Oral contraceptives and yenous thromboembolic disease, surgically confirmed gallbladder disease, and breast tumours. Lancet $1973 ; \mathrm{i}: 1399-1404$.

${ }^{32}$ Zumoff B, Strain GW, Kream J, O'Connor J, Levin J, Fukushima DK. Obese young men have elevated plasma estrogen levels but obese premenopausal women do not. Metabolism 1981;30:1011-14.

${ }^{3}$ Bailey CJ, Ahmed-Sorour H. Role of ovarian hormones in the long-term control of glucose homeostasis: effects on insulin secretion. Diabetologia 1980;19:475-81. $\mathrm{Kim} \mathrm{HJ}$, Kalkhoff RK. Sex steroid influence in triglyceride metabolism. $\mathcal{F}$ Clin Invest $1975 ; 56: 888-96$

3 Orchard TJ, Becker DJ, Kuller LH, Wagener DK, LaPorte RE, Drash AL. Age and sex variations in glucose tolerance and insulin responses: parallels with

Wynn V Adams PW. Godsland I

(ifferent combined oral-contracep

$\because$ Puavilai G, Drobny EC, Domont LA, Baumann G. Insulin receptors and insulin resistance in human pregnancy: evidence for a postreceptor defect in insulin action. $\mathcal{J}$ Clin Endocrinol Metab 1982;54:247-53.

${ }^{3 *}$ Elahi D, Nagulesparan M, Hershcopf RJ, et al. Feedback inhibition of insulin secretion by insulin: relation to the hyperinsulinemia of obesity. $N$ Engl f Med 1982;306:1196-1202.

Nepokroeff CM, Lakshmanan MR, Ness GC, Dugan RE. Porter JW. Regulation of the diurnal rhythm of rat liver B-hydroxy-B-methylglutaryl coenzyme A reductase activity by insulin, glucagon, cyclic AMP and hydrocortisone. Arch Biochem Biophysics 1974;160:387-9 "Wilson JD. The role of bile acids in the overall regulation of steroid metabolism
Arch Intern Med 1972;130:493-505.
${ }^{11}$ Brunzell JD. Obesity, diabetes and hypertriglyceridemia. In: Bjorntop P, Cairella $M$, Howard AN, eds. Recent advances in obesity research III. London: John Libbey, 1980:239-47.

"Larsen JA, Christensen KD. Insulin-stimulated bile formation in cats. Acta

Physiol Scand 1978;102:301-9.
${ }^{3}$ Storer GB, Topping DL, Trimble RP. Direct stimulation by glucose and insulin of glycogen synthesis in perfused rat liver. FEBS Letters 1981;136:135-7.

ping DL, Mayes PA. Insulin and non-esterified fatty acids. acute regulators of lipogenesis in perfused rat liver. Biochem

- and hyper-lipoprcteinaemia. Acta Med Scand 1977;suppl 610.

Sodhi HS, Kudchodkar BJ. Correlating metabolism of plasma and tissuecholesterol with that of plasma-lipoproteins. Lancet 1973;i:513-9.

Royal College of General Practitioners' Oral Contraception Study. Oral contraScragg RKR, McMichael AJ, Seamark RF. The role of oral contraceptives, pregnancy, and endogenous oestrogen in gallstone disease: a case-control study. $B r$ Med f 1984;288:1795-9.

"9 Cahlin E, Jonsson J, Nilsson S, Schersten T. Biliary lipid composition in normolipidemic and prebeta hyperlipoproteinemic gallstone patients. Scand $\mathcal{f}$

Van der Linden W. Some biological traits in female gallstone-disease patients. Acta Chir Scand 1961 ;suppl 269.

Chers ML. Serum cholesterol levels in southwestern American Indians. $\mathcal{F}$ Chron Dis $1968 ; 21: 107-15$.

${ }^{32}$ Savage PJ, Hamman RF, Bartha G, Dippe SE, Miller M, Bennett PH. Serum cholesterol levels in

s3 Garnick MB, Bennett PH, Langer T. Low density lipoprotein metabolism and lipoprotein cholesterol content in southwestern American Indians. F Lipid Res $1979 ; 20: 31-9$.

st Albers JJ, Grundy SM, Cleary PA, Small DM, Lachin JM, Schoenfield LJ. National Cooperative Gallstone Study: The effect of chenodeoxycholic acid on lipoproteins and apolipoproteins. Gastroenterol $1982 ; 82: 638-46$.

${ }^{5}$ Nervi FO, Dietschy JM. Ability of six different lipoprotein fractions to regulate the rate of hepatic cholesterogenesis in vivo. F Biol Chem 1975;250:8704-11.

Andersen JM, Nervi FO, Dietschy JM. Rate constants for the uptake of cholestero from various intestinal and serum lipoprotein frac

Boyd GS, Onajobi FD. Control of cholesterol biosynthesis by a plasma apolipoprotein. Nature 1969;221:574-5.

"Schwartz CC, Berman M, Vlahcevic ZR, Halloran LG, Gregory DH, Swell L. Multicompartmental analysis of cholesterol metabolism in man. Characterization of the hepatic bile acid and biliary cholesterol precursor sites. F Clin Invest 1978; 61:408-23.

Halloran LG, Schwartz CC, Vlahcevic ZR, Nisman RM, Swell L. Evidence for high-density lipoprotein-free cholesterol as the primary precursor for bile acid

synthesis in man. Surgery 1978;84:1-7.
"0 Portman OW, Alexander M, O'Malley JP. Metabolism of free and esterified cholesterol and apolipoproteins of plasma low and high density lipoproteins. Biochim Biophys Acta 1980;619:545-58.

\title{
Omeprazole in duodenal ulceration: acid inhibition, symptom relief, endoscopic healing, and recurrence
}

\author{
COOPERATIVE STUDY*
}

\begin{abstract}
In a preliminary study to compare the effects of different doses of omeprazole 44 patients with endoscopically diagnosed duodenal ulceration randomly received omeprazole $20 \mathrm{mg}, 30 \mathrm{mg}, 40 \mathrm{mg}$, or $60 \mathrm{mg}$ daily for four weeks. After four weeks the ulcer had healed in 41 of the 43 patients who completed the course of treatment; the proportions of patients whose ulcer healed were similar between the four dosage groups. Most patients were symptom free after one week of treatment. Seven patients reported a total of eight adverse events. With the exception of one patient who had persistent nausea and was
\end{abstract}

*Members of the cooperative study group were: J Meyrick-Thomas, J J Misiewicz, I F Trotman (Central Middlesex Hospital, London); E J S Boyd, J A Wilson, K G Wormsley (Ninewells Hospital, Dundee); R E Pounder, B K Sharma (Royal Free Hospital, London); N Collier, J Spencer, J Thompson (Royal Postgraduate Medical School, London); J H Baron, A Bush, L Cope (St Charles Hospital, London); and M J Daly, A L Howe (Astra Clinical Research Unit, Edinburgh and Kings Langley).

Correspondence to: Mrs A Howe, Astra Clinical Research Unit, Astra Pharmaceuticals Ltd, Home Park Estates, Kings Langley, Hertfordshire. withdrawn from the study, all the adverse events resolved spontaneously during continued treatment with the same dose of omeprazole. Pentagastrin tests were performed before the study and after four weeks' treatment. The mean inhibition of peak acid output measured 24 hours after the last dose was $61 \%, 94 \%, 91 \%$, and $81 \%$ with omeprazole $20 \mathrm{mg}, 30 \mathrm{mg}, 40 \mathrm{mg}$, and $60 \mathrm{mg}$ respectively. During the first six months after the end of treatment 11 out of 36 patients had a symptomatic, endoscopically diagnosed recurrence of ulceration; the median time to relapse was 10 (range 6-23) weeks.

\section{Introduction}

Omeprazole $(\mathrm{H} 168 / 68)$ is a substituted benzimidazole that inhibits secretion of gastric acid by interacting with the enzyme $\mathrm{H}^{+}, \mathrm{K}^{+}$-ATPase, believed to be the proton pump of the parietal cell. ${ }^{1-3}$ Studies in healthy subjects have shown that omeprazole produces a dose dependent inhibition of basal and pentagastrin stimulated acid secretion that is long lasting and maximal after five to seven days of treatment. ${ }^{4-6}$ In patients with duodenal ulceration omeprazole $30 \mathrm{mg}$ daily for one week caused a $95 \%$ decrease in 24 hour intragastric acidity. ${ }^{7}$ Recently it was reported that duodenal ulcers healed in $93 \%$ of patients after two weeks 
treatment with omeprazole $40 \mathrm{mg}$ daily and in all patients after four weeks' treatment. ${ }^{8}$

We compared healing of duodenal ulcers and acid inhibition after oral omeprazole $20 \mathrm{mg}, 30 \mathrm{mg}, 40 \mathrm{mg}$, or $60 \mathrm{mg}$ once daily for four weeks.

\section{Patients and methods}

Outpatients with symptomatic duodenal ulcers verified endoscopically were admitted to a four week open trial, which was conducted in five British hospitals with the approval of the local ethical committees and with the patients' informed consent. Omeprazole was started within five days after endoscopy and initial clinical, haematological, and biochemical assessments. Patients were excluded if they had concurrent gastric ulceration, pyloric stenosis, or a serious disease, had had a previous gastric operation, or had taken an antiulcer drug (other than antacids) during the two weeks preceding entry into the trial.

Each centre compared either omeprazole $20 \mathrm{mg}$ with $40 \mathrm{mg}$ or omeprazole $30 \mathrm{mg}$ with $60 \mathrm{mg}$, and patients were randomly allocated to take one of these doses each morning before breakfast for 28 days. Omeprazole was administered orally as enteric coated granules contained in hard gelatin capsules. During the study standard prepacked antacid tablets (Rennies, Nicholas Laboratories) were supplied to relieve pain. Patients were asked to record the number of antacid tablets taken each day. To measure compliance, counts were made of the omeprazole capsules and antacids that were returned.

Ulcer symptoms and spontaneously reported adverse events were assessed by a physician in each centre before treatment and on days 8,15 , and 29 of the study. Patients were also asked to record the whose ulcers healed was similar between the groups, being $9 / 10$, $12 / 12,9 / 10$, and $11 / 11$ patients taking omeprazole $20 \mathrm{mg}, 30 \mathrm{mg}, 40$ $\mathrm{mg}$, and $60 \mathrm{mg}$ respectively. One patient, taking omeprazole $40 \mathrm{mg}$, whose prepyloric ulcer had healed but whose duodenal ulcer had not, was classified as not healed.

In 26 patients peak acid output was measured before and 24 hours after the end of treatment. The mean percentage inhibitions in the patients taking $20 \mathrm{mg}, 30 \mathrm{mg}, 40 \mathrm{mg}$, and $60 \mathrm{mg}$ were respectively $61 \%, 94 \%, 91 \%$, and $81 \%$ (figure). As the number of patients in each treatment group was small and the confidence intervals wide differences between the four doses could not be established. Peak acid output measured in 10 patients before and one week after the end of treatment was not significantly different $(p>0.05$, Wilcoxon matched pairs signed ranks test).

All patients had symptoms before starting treatment (table II), 42 having pain in the day and 31 at night. After the first week of treatment only seven patients had pain in the day and five pain at night. After four weeks only one patient had occasional pain during the day and night and one other mild pain during the day. Fewer patients experienced nausea and vomiting than pain before the start of the study, and after two weeks of treatment these symptoms had resolved in all but two patients. Nausea persisted in one patient, who was withdrawn from the study on day 26 . After the first week 32 patients reported that they were asymptomatic, 10 that their symptoms had improved, and only one patient that his symptoms were of unchanged severity. By the end of the four weeks almost all the patients reported that their symptoms had gone. The diary cards confirmed infrequent episodes of pain and minimal consumption of antacids.

Six patients reported a total of seven transient adverse events, all of which resolved during continued treatment with the same dose of omeprazole. These included one patient taking omeprazole $20 \mathrm{mg}$ daily who had diarrhoea and a severe cold accompanied by

TABLE I-Details of 43 patients who completed four weeks of treatment

\begin{tabular}{|c|c|c|c|c|c|}
\hline & \multirow[b]{2}{*}{$\underset{(\mathrm{n}=43)}{\text { All patients }}$} & \multicolumn{4}{|c|}{ Daily dose of omeprazole } \\
\hline & & $\begin{array}{c}20 \mathrm{mg} \\
(\mathrm{n}=10)\end{array}$ & $\begin{array}{c}30 \mathrm{mg} \\
(\mathrm{n}=12)\end{array}$ & $\begin{array}{l}40 \mathrm{mg} \\
(\mathrm{n}=10)\end{array}$ & $\begin{array}{l}60 \mathrm{mg} \\
(\mathrm{n}=11)\end{array}$ \\
\hline $\begin{array}{l}\text { Mean age (years) (range) } \\
\text { Smokers:non-smokers } \\
\text { Drinkers:non-drinkers } \\
\text { Mean duration of disease (years) (range) } \\
\text { Mean duration of current episode (days) (range) }\end{array}$ & $\begin{array}{c}43(20-65) \\
26: 17 \\
36: 7 \\
10(1-25) \\
43(3-200)\end{array}$ & $\begin{array}{c}49(26-65) \\
8: 2 \\
10: 0 \\
8(5-10) \\
34(3-90)\end{array}$ & $\begin{array}{c}40(25-51) \\
7: 5 \\
11: 1 \\
13(6-25) \\
59(3-200)\end{array}$ & $\begin{array}{c}45(23-63) \\
5: 5 \\
6: 4 \\
7(1-20) \\
38(3-90)\end{array}$ & $\begin{array}{l}39(20-57) \\
6: 5 \\
9: 2 \\
12(8-19) \\
41(10-90)\end{array}$ \\
\hline
\end{tabular}

daily number of attacks of pain due to the ulcer on a diary card. Healing of the ulcer, assessed by repeat endoscopy at four weeks, was defined as complete epithelialisation of all craters. The gastric response to a maximal dose of pentagastrin was measured, using a standard procedure, within five days of inclusion in the study and 24 hours (four hospitals) or seven days (one hospital) after completion of treatment. After intubation with a nasogastric tube a maximal dose of pentagastrin $(6 \mu \mathrm{g} / \mathrm{kg} / \mathrm{h}$ intravenously, $1.5 \mu \mathrm{g} / \mathrm{kg} / \mathrm{h}$ intravenously, $6 \mu \mathrm{g} / \mathrm{kg} / \mathrm{h}$ intramuscularly, or $600 \mu \mathrm{g}$ subcutaneously) was administered and the gastric contents collected in 15 minute fractions for 60 90 minutes. The $\mathrm{pH}$, volume, and acid output were measured for each sample and the peak response to pentagastrin taken as the sum of the two highest consecutive 15 minute acid outputs multiplied by two and expressed in $\mathrm{mmol} / \mathrm{h}$. Routine haematological and biochemical tests, including liver and thyroid function tests, were performed on days 15 and 29.

Patients whose ulcers healed were followed up for a further six months after stopping treatment. During this period they took only an tacids to relieve occasional minor episodes of pain. Patients who had three or more consecutive days of pain returned for endoscopy.

\section{Results}

Forty four patients (43 men, one postmenopausal woman) entered the study, of whom 43 completed the four weeks of treatment (one patient was lost to follow up after two weeks). The demographic details of the four treatment groups were similar (table I). Ulcers healed in 41 of the 43 patients (this includes one patient whose ulcer healed satisfactorily but who had to be withdrawn from the study after the 26 th dose because of persistent nausea). The proportion of patients
TABLE II-Numbers of patients reporting symptoms of ulcers before and 8, 15, and 29 days after taking omeprazole $20-60 \mathrm{mg}$ daily

\begin{tabular}{lcccc}
\hline & Before study & Day 8 & Day 15 & Day 29 \\
\hline Pain in daytime & 42 & 7 & 5 & 2 \\
Pain at night & 31 & 5 & 3 & 1 \\
Nausea & 10 & 4 & 2 & 1 \\
Vomiting & 5 & & 2 & \\
\hline
\end{tabular}

herpes labialis; one who had a stuffy nose while taking omeprazole $30 \mathrm{mg}$; three taking omeprazole $40 \mathrm{mg}$, two of whom had diarrhoea and the other experienced mild dizziness; and, lastly, one patient who reported numbness in the fingertips while taking omeprazole $60 \mathrm{mg}$. One further patient taking omeprazole $40 \mathrm{mg}$ complained of persistent severe nausea and was withdrawn from the study on day 26.

Several abnormal laboratory values were recorded before and during treatment. Most were just outside the normal range and were considered not to be of clinical importance. Nine patients had abnorinal liver enzyme activities before treatment. In three these returned to normal during treatment, and in the remaining six they persisted unchanged. A further four patients developed abnormal enzyme activities during the study (table III): in two they returned to normal during treatment, and in the remaining two marginally increased values were noted on both day 15 and day 29 . There were no changes in the results of thyroid function tests. Overall, there were no significant trends in any of the laboratory values measured.

Thirty six of the 41 patients whose ulcers healed were followed up for six months (four patients could not be contacted, and one patient had a dissecting aneurysm and died). During the six months after stopping omeprazole treatment 16 of these 36 patients experienced 
pain and returned to the hospital for endoscopy. Duodenal ulcers were present in 11. Of the remaining five patients, two had duodenitis, two erosions, and one oesophagitis. The median time to relapse was 10 (range 6-23) weeks, and the proportion of patients who relapsed was similar between the treatment groups (figure).

\section{Discussion}

After four weeks of treatment with omeprazole $20-60 \mathrm{mg}$ daily duodenal ulceration had healed in 41 of 43 patients $\left(95_{0}^{\circ}\right)$. Ulcers healed in all patients in one study given omeprazole $40 \mathrm{mg}$ once daily for four weeks, ${ }^{8}$ and in $84 \%$ and $96 \%$ of patients after two weeks and four weeks' treatment respectively with 20 or $60 \mathrm{mg}$ omeprazole daily. ${ }^{9}$ In early open studies with $\mathrm{H}_{2}$ antagonists healing of duodenal ulcer was achieved in 78$88^{\circ} \%$ of patients given cimetidine $(1 \mathrm{~g} / \text { day })^{10}$ and $79-94 \%$ of those given ranitidine (150 mg twice daily). ${ }^{11}$ The proportion of patients whose ulcers heal with $\mathrm{H}_{2}$ antagonists is now, however, generally accepted to be about $70-80 \%$ after four weeks' treatment. ${ }^{12} 13$

All four doses of omeprazole rapidly reduced pain due to the ulcer. Before treatment $98 \%$ of the patients had pain during the day and $72 \%$ pain at night, whereas after one week $84 \%$ had no daytime pain and $88 \%$ were pain free at night. Thus symptom relief is at least as good as that afforded by $\mathrm{H}_{2}$ receptor antagonists. ${ }^{12}$

The beneficial effects of $\mathrm{H}_{2}$ antagonists are attributed to

TABLE III-Individual findings in four patients in whom liver enzyme activities became abnormal during treatment

\begin{tabular}{|c|c|c|c|c|c|c|c|}
\hline \multirow[b]{2}{*}{$\begin{array}{l}\text { Case } \\
\text { No }\end{array}$} & \multirow[b]{2}{*}{$\begin{array}{l}\text { Omeprazole } \\
\text { dose }(\mathrm{mg})\end{array}$} & \multirow[b]{2}{*}{$\begin{array}{l}\text { Alcohol consumption } \\
\text { on entry (drinks/day)* }\end{array}$} & \multirow[b]{2}{*}{ Enzyme } & \multicolumn{4}{|c|}{ Enzyme activities (IU/1) } \\
\hline & & & & $\begin{array}{l}\text { Normal } \\
\text { range }\end{array}$ & $\begin{array}{l}\text { Before } \\
\text { study }\end{array}$ & $\mathrm{Day}_{15}$ & $\begin{array}{c}\text { Day } \\
29\end{array}$ \\
\hline 1 & 30 & Irregular & $\left\{\begin{array}{l}\gamma \text {-Glutamyltransferase } \\
\text { Aspartate transferase } \\
\text { Alanine transferase }\end{array}\right.$ & $\begin{array}{c}\text { Not done } \\
40 \\
40\end{array}$ & $\begin{array}{l}32 \\
40\end{array}$ & ${ }_{33}^{48 \dagger}$ & $\begin{array}{l}44+ \\
51+\end{array}$ \\
\hline & & & $\gamma$-Glutamyltransferase & $<40$ & $\begin{array}{l}40 \\
18\end{array}$ & & 16 \\
\hline 2 & 40 & 5 & $\{$ Aspartate transferase & $<40$ & 36 & $47+$ & 32 \\
\hline & & & $\gamma$-Glutamyltransferase & $\begin{array}{r}40 \\
<50\end{array}$ & 35 & $54+$ & $56+$ \\
\hline 3 & 60 & 5 & Aspartate transferase & $<35$ & 19 & 21 & $37^{+}$ \\
\hline & & & $\begin{array}{l}\text { Alanine transterase } \\
\gamma \text {-Glutamyltransferase }\end{array}$ & $\begin{array}{l}\text { Not done } \\
\text { Not done }\end{array}$ & & & \\
\hline 4 & 60 & 1 & Aspartate transferase & $<40$ & 31 & $58 \dagger$ & 26 \\
\hline
\end{tabular}

* One drink $=1$ pint of beer, one measure of spirit, one glass of wine.

+Abnormal value.
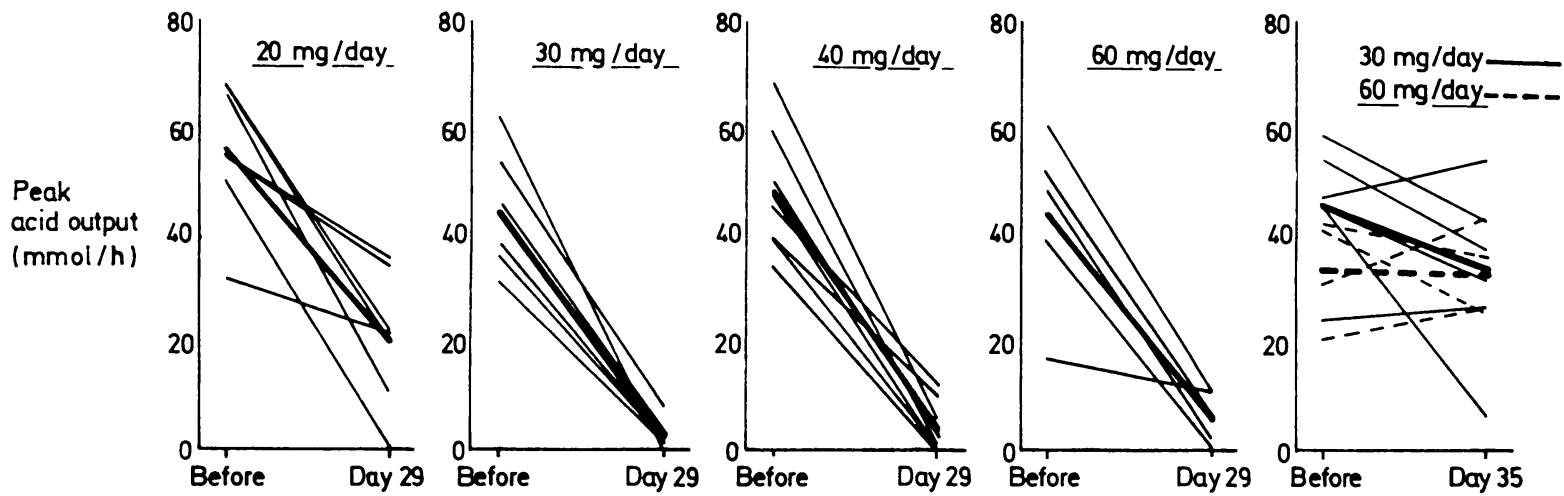

Inhibition of peak

acid output $(\%)$ :

\begin{tabular}{|c|c|c|c|c|c|}
\hline Mean & $61 \quad(n=7)$ & $94(n=6)$ & $91(n=8)$ & $81(n=5)$ & $\left\{\begin{array}{l}30 \mathrm{mg}: 25 \\
60 \mathrm{mg}:-5\end{array}\right\} \quad n=10$ \\
\hline Range & $31-100$ & $85-100$ & $73-100$ & $39-98$ & 85 to -41 \\
\hline $\begin{array}{l}\text { Confidence value } \\
\text { for range as } \\
\text { confidence interval } \\
(\%)\end{array}$ & 98 & 97 & 99 & 93 & 100 \\
\hline \multicolumn{6}{|l|}{ Icers healed: } \\
\hline No $(\%)$ & $9 / 10(90)$ & $12 / 12(100)$ & $9 / 10(90)$ & $11 / 11(100)$ & Overall 41/43 (95) \\
\hline $\begin{array}{l}95 \% \text { confidence } \\
\text { limits }\end{array}$ & $56-100$ & $74-100$ & $56-100$ & $72-100$ & $84-99$ \\
\hline \multicolumn{6}{|l|}{ elapses: } \\
\hline No $(\%)$ & $2 / 7(29)$ & $3 / 11(27)$ & $3 / 7(43)$ & $3 / 11(27)$ & Overall $11 / 36$ (31) \\
\hline $\begin{array}{l}95 \% \text { confidence } \\
\text { limits }\end{array}$ & $4-71$ & $6-61$ & $10-82$ & $6-61$ & $16-48$ \\
\hline
\end{tabular}

Peak acid output before treatment and 24 hours after 28 th dose of omeprazole $20,30,40$, and 60 mg and seven days after end of treatment with omeprazole 30 and $60 \mathrm{mg}$ (bold lines are mean values).

Conversion: SI to traditional units-Acid output: $1 \mathrm{mmol} / \mathrm{h}=1 \mathrm{mEq} / \mathrm{h}$. 
inhibition of secretion of gastric acid. Omeprazole, which produces more profound and longer lasting inhibition of acid secretion, presumably acts in a similar manner. In this preliminary open study, with a limited number of patients, no differences could be established between the four different doses of omeprazole with respect to inhibition of pentagastrin stimulated secretion of gastric acid and ulcer healing. Thus as all the doses of omeprazole tested appeared to be effective and there was no dose dependent relation with adverse events recorded during the study, larger comparative studies are required to determine the optimal therapeutic dose of omeprazole for ulcer healing.

However effective a drug is in healing ulcers in the short term, patients are liable to relapse once treatment is withdrawn. In this study 11 out of 36 patients $(31 \%$ ) whose ulcers had healed after four weeks of treatment with omeprazole had a symptomatic relapse, diagnosed endoscopically, within six months after stopping treatment. Cumulative incidences of recurrence of 50$60 \%$ have been reported six months after successful short term healing with $\mathrm{H}_{2}$ antagonists. ${ }^{14-17}$

In conclusion, omeprazole $20-60 \mathrm{mg}$ given once daily for four weeks was well tolerated and healed 41 of 43 duodenal ulcers diagnosed endoscopically; 32 patients were asymptomatic within one week. Eleven out of 36 patients had a relapse during the first six months after stopping treatment. Comparative clinical trials will assess the place of omeprazole in treating peptic ulcer.

We thank Dr D Burnett of the department of clinical biochemistry, St Albans City Hospital, for laboratory analyses; Mr J J Breslin for help with the computer programming; Miss J Roberts for adminis- trative and secretarial help; and Mrs C Wright for help with collating and editing data.

\section{References}

1 Fellenius E, Berglindh T, Sachs G, et al. Substituted benzimidazoles inhibit gastric acid secretion by blocking $\left(\mathrm{H}^{-}+\mathrm{K}+\right.$ ) A TPase. Nature $1981 ; 290: 159-61$. 149/94) on gastric acid secretion in humans. Gastroenterology 1982:83:193-8.

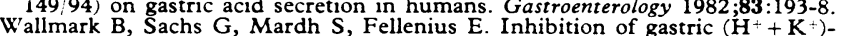
ATPase by the substituted benzimidazole picoprazole. Biochim Biophys Acta 1983;728:31-8.

4 Muller P, Dammann H-G, Seitz H, Simon B. Effect of repeated, once daily, oral omeprazole on gastric secretion. Lancet $1983 ; \mathrm{i}: 66$.

5 Howden CW, Reid JL, Forrest JAH. Effect of omeprazole on gastric acid

6 Lind T, Cederberg C, Ekenved G, Haglund U, Olbe L. Effect of omeprazolea gastric proton pump inhibitor-on pentagastrin stimulated acid secretion in man. Gut 1983;24:270-6.

7 Walt RP, Gomes MdeFA, Wood EC, Logan LH, Pounder RE. Effect of daily oral omeprazole on 24 hour intragastric acidity. $\mathrm{Br}$ Med $\mathcal{F} 1983 ; 287: 12-4$.

alan A, Bergasker-Aspoy J, Farup P, et al. Four week study of the rate of duodenal ulcer healing with omeprazole. Gut 1983;24:A972.

Gustavsson S, Adami H-O, Loof L, Nyberg A, Nyren O. Rapid healing of duodenal ulcers with omeprazole. Scand $\mathcal{F}$ Gastroenterol 1983;18, suppl 86:21. Westminster Hospital symposium. Edinburgh: Churchill Livingstone, 1978: 31-56.

11 Brogden RN, Carmine AA, Heel RC, Speight TM, Avery GS. Ranitidine: a review of its pharmacology and therapeutic use in peptic ulcer disease and other allied diseases. Drugs 1982;24:267.

12 Feely J, Wormsley $\mathrm{KG}_{\text {. }} \mathrm{H}_{2}$ receptor antagonists-cimetidine and ranitidine. Br Med $\mathcal{f} 1983 ; 286: 695$.

13 Anonymous. Cimetidine and ranitidine [Editorial]. Lancet 1981 ;i:29-30.

14 Bardhan KD, Cole DS, Hawkins BW, Franks CR. Does treatment with cimetidine extended beyond initial healing of duodenal ulcer reduce the subsequent relapse rate? Br Med F 1982;284:621-3.

15 Burland WL, Hawkins BW, Beresford J. Cimetidine treatment for the prevention of recurrence of duodenal ulcer: an international collaborative study. Postgrad Med f 1980;56:173-6.

16 Korman MG, Hansky J, Merrett AC, Schmidt GI. Ranitidine in duodenal 17 I ulcer. Incidence of healing and effects of smoking. Dig Dis Sci $1982 ; 27: 712-5$. ment with cimetidine or antacid. Gastroenterology 1983;85:875-80.

(Accepted 21 fune 1984)

\title{
Lateral subcutaneous sphincterotomy versus anal dilatation in the treatment of fissure in ano in outpatients: a prospective randomised study
}

\author{
STEEN LINDKÆR JENSEN，FLEMING LUND， OLE VAGN NIELSEN，GUDMUND TANGE
}

\begin{abstract}
Fifty eight patients with idiopathic chronic anal fissure were included in a randomised prospective trial of liateral subcutaneous sphincterotomy versus simple anal dilatation carried out as outpatient procedures. Operations were performed under local anaesthesia and the patients reviewed 10-30 months later (median follow up time 18 months).

Altogether 30 patients were treated by lateral subcutaneous sphincterotomy and 28 by anal dilatation. No serious complications were observed in either group. One recurrence was observed in the group treated by sphincterotomy, whereas eight occurred in the other group $(p<0.05)$. Functional results with respect to
\end{abstract}

Surgical Clinic, Lægehuset Rønnebaeralle, Elsinore, Denmark

STEEN LINDKAR JENSEN, MD, PHD, senior registrar

FLEMING LUND, MD, PHD, senior registrar

OLE VAGN NIELSEN, MD, PHD, associate professor of surgery

GUDMUND TANGE, MD, consultant surgeon

Correspondence to: Dr Steen Lindkær Jensen, Department of Surgery D, Rigshospitalet, Blegdamsvej 9, DK-2100 Copenhagen Ø, Denmark. impaired control of flatus and soiling of underwear were significantly better after sphincterotomy $(p<0.002)$.

It is concluded that lateral subcutaneous sphincterotomy is the treatment of choice for idiopathic chronic anal fissure resistant to conservative measures.

\section{Introduction}

Surgical procedures for idiopathic chronic anal fissure resistant to conservative treatment include lateral subcutaneous sphincterotomy and simple anal dilatation. Which of these is the most favourable, however, is a subject of controversy. ${ }^{1}$ We have therefore carried out a controlled prospective trial of the two procedures, performed in the outpatient department. The treatments were allocated at random.

\section{Patients and methods}

All patients presenting to the clinic with idiopathic chronic anal fissure during June 1980 to December 1982 were considered for the trial. Patients were accepted provided that induration of the edges of the fissure and exposure of the fibres of the internal sphincter in the floor of the fissure were observed on examination.

Patients were admitted to the clinic by their general practitioner. 